\title{
Purification and Properties of Glucose 6-Phosphate Dehydrogenase from Aspergillus aculeatus
}

\author{
Omodele Ibraheem ${ }^{\dagger}$ Isaac Olusanjo Adewale and Adeyinka Afolayan* \\ Department of Biochemistry, Obafemi Awolowo University, Ile-Ife, Nigeria
}

Received 30 April 2005, Accepted 7 July 2005

\begin{abstract}
Glucose 6-phosphate dehydrogenase (EC 1.1.1.49) was purified from Aspergillus aculeatus, a filamentous fungus previously isolated from infected tongue of a patient. The enzyme, apparently homogeneous, had a specific activity of 220 units $\mathrm{mg}^{-1}$, a molecular weight of $105,000 \pm 5,000$ Dal by gel filtration and subunit size of $52,000 \pm 1,100$ Dal by sodium dodecyl sulphate-polyacrylamide gel electrophoresis. The substrate specificity was extremely strict, with glucose 6phosphate (G6P) being oxidized by nicotinamide adenine dinucleotide phosphate (NADP) only. At assay pH of 7.5, the enzyme had $K_{m}$ values of $6 \mu \mathrm{M}$ and $75 \mu \mathrm{M}$ for NADP and G6P respectively. The $k_{\text {cat }}$ was $83 s^{-1}$. Steady-state kinetics at pH 7.5 produced converging linear Lineweaver-Burk plots as expected for ternary-complex mechanism. The patterns of product and dead-end inhibition suggested that the enzyme can bind NADP and G6P separately to form a binary complex, indicating a random-order mechanism. The enzyme was irreversibly inactivated by heat in a linear fashion, with G6P providing a degree of protection. Phosphoenolpyruvate (PEP), adenosinetriphosphate (ATP), and fructose 6-phosphate (F6P), in decreasing order, are effective inhibitors. Zinc and Cobalt ions were effective inhibitors although cobalt ion was more potent; the two divalent metals were competitive inhibitors with respect to G6P, with $K_{i}$ values of $6.6 \mu M$ and $4.7 \mu \mathrm{M}$ respectively. It is proposed that inhibition by divalent metal ions, at low NADPH /NADP ratio, is another means of controlling pentosephosphate pathway.
\end{abstract}

Keywords: Aspergillus aculeatus, Glucose 6-phosphate dehydrogenase, Inhibitors, Kinetics, Molecular weight, Purification

\footnotetext{
'Part of the thesis presented by O.I. in partial fulfillment for the degree of Master of Science (Biochemistry) of the Obafemi Awolowo University, Ile-Ife.
}

*To whom correspondence should be addressed.

Tel: Fax: 234-0803-670-5864

E-mail: aafolay@oauife.edu.ng, adeyinkaafolayan@yahoo.co.uk

\section{Introduction}

Glucose 6-phosphate dehydrogenase (G6PD) (EC.1.1.1.49), an enzyme that catalyses the first step in the pentosephosphate pathway, is widely distributed among the prokaryotes and the eukaryotes (Levy, 1979). In the filamentous fungi, which include the species of Aspergillus, reduced nicotinamide adenine dinucleotide phosphate (NADPH) is produced by the pentosephosphate and mannitol pathways (McCullough et al., 1977; Hult and Gatenbeck, 1978). While NADPH produced by the oxidative pathway in the fungi is targeted towards lipid biosynthesis (Levy, 1979), the reduced coenzyme from the mannitol cycle is channeled towards the synthesis of polyols and polyketides such as versicolorin A, a precursor of aflatoxin (Hult and Gatenbeck, 1978; Niehaus and Dilts, 1982; Dijkema et al., 1986). Detailed studies of G6PD from filamentous fungi are not many. Amongst those studied are, glucose-6-phosphate dehydrogenases from Aspergillus niger (Jagannathan et al., 1956), Aspergillus niger and Aspergillus nidulans (Wennekes et al., 1993), Penicillium duponts and $P$. notatum (Malcolm and Shepherd, 1972) and Aspergillus parasiticus (Niehaus and Dilts, 1984); all of which have been well characterized. The regulation of the activity of G6PD in the fungi will, no doubt, be of scientific interest in view of the interrelationship between the mannitol cycle and the oxidative pentose pathway.

Aspergillus aculeatus is a filamentous fungus that attracted attention some years ago because Williams and his coworkers (Williams et al., 1984) reported that it caused black tongue disease in infected individuals. The only known other report on this organism is that of Olutiola and Nwaogwugwu (1982) on its growth, sporulation and production of certain extracellular enzymes. We consider it plausible that the control of one of the enzymatic reactions in the organism could be one of the strategies that could be used in the therapeutic control of the infection by the fungus. The pentosephosphate pathway is an important metabolic pathway to most living organisms considering the fact that its products, such as NADPH and ribose sugars, are required for biosynthetic reactions. We have 
therefore focused on the G6PD in this fungus as part of the overall study of the biochemistry of this infectious organism.

\section{Experimental Procedures}

Materials A. aculeatus (Lizuka) which was kindly supplied by A. Ajayi (Department of Microbiology of this University) had previously been characterized (Williams et al., 1984). Substrates, nucleotides, reactive blue -2 agarose, molecular weight standards for SDS gel electrophoresis and gel filtration, and blue dextran were obtained from Sigma Chemical Co. (St. Louis, USA) All other reagents were of analytical grade.

Growth of microorganism The conidiophores of $A$. aculeatus grown on saboroud dextrose were harvested and used to inoculate $500 \mathrm{ml}$ of sterile minimal medium containing $2 \%(\mathrm{w} / \mathrm{v})$ glucose (Cruickshank et al., 1975). The mixture was shaken vigorously in a shaker at $25^{\circ} \mathrm{C}$ for $10 \mathrm{~min}$ before it was added to 3.5 litres of the same medium. The growth medium, in aliquots of $400 \mathrm{ml}$, was dispensed into five different 2 litre flasks. The cultures were kept for $96 \mathrm{~h}$ at $25^{\circ} \mathrm{C}$ without agitation or bubbling. Mycelia were harvested by suction filtration and were extensively washed with deionized water before being blotted dry. An approximate $160 \mathrm{~g}$ of mycelia were obtained from a 4 liter culture.

Extraction and purification of enzyme The harvested mycelia were homogenized in a porcelain mortar immersed in ice with acidwashed sand at a ratio $1: 2$ (mycelia to sand) in $0.02 \mathrm{M}$ sodium phosphate buffer $\mathrm{pH} 6.8$ containing $2 \mathrm{mM} \mathrm{MgCl}_{2}, 1 \mathrm{mM}$ EDTA and $50 \mu \mathrm{M} \varepsilon$-amino -n-caproic acid (buffer A). Approximately, the ratio of mycelia to homogenizing buffer A was $1: 2(\mathrm{v} / \mathrm{v})$. The homogenate was centrifuged at $12,000 \mathrm{~g}$ for $20 \mathrm{mins}$ in MSE Mistral 6000 refrigerated centrifuge. The clear supernatant was brought to $15 \%$ ammonium sulphate saturation by the addition of solid ammonium sulphate ( $84 \mathrm{~g} /$ litre). The precipitate formed was collected by centrifugation for $20 \mathrm{~min}$ and was discarded. The supernatant was taken to $65 \%$ saturation by adding solid ammonium sulphate ( $333 \mathrm{~g} /$ liter). The precipitate that was formed was collected and suspended in a minimum volume of buffer $\mathrm{A}$ before being dialysed extensively for $24 \mathrm{~h}$ at $4^{\circ} \mathrm{C}$ against the same buffer, with several changes.

The dialysed enzyme was loaded on to a reactive blue-2 agarose column $(1.5 \times 5.7 \mathrm{~cm})$ that was previously equilibrated with buffer A. After washing the column with $100 \mathrm{ml}$ of buffer $\mathrm{A}$, at a flow rate of $20 \mathrm{ml} / \mathrm{h}$, the enzyme was eluted by washing the column with another $100 \mathrm{ml}$ of buffer $\mathrm{A}$ that contained $2 \mathrm{M} \mathrm{NaCl}$ and $25 \mu \mathrm{M}$ NADP.

The peak fractions containing enzyme activity were pooled and the pool was concentrated by dialysis against saturated ammonium sulphate (70\%) in buffer A containing $25 \mu \mathrm{M}$ NADP.

The precipitate obtained was suspended in a minimum volume of buffer A which contained $25 \mu \mathrm{M}$ NADP. The enzyme suspension was desalted on Sephadex G-25 and later layered on a column of Sephacryl S-200 that was previously equilibrated with buffer A containing $25 \mu \mathrm{M}$ NADP. The enzyme was eluted with the same buffer at a flow-rate of $10 \mathrm{ml} / \mathrm{h}$ and fractions of $3 \mathrm{ml}$ were collected.
Again, peak fractions were pooled and dialysed against $70 \%$ saturated ammonium sulphate in buffer A that contained $25 \mu \mathrm{M}$ NADP. The stability of the enzyme under this condition did not go beyond 3 months.

Polyacrylamide gel electrophoresis Sodium dodecyl sulphate polyacrylamide gel electrophoresis, containing $7.5 \%$ polyacrylamide, was run according to the method of Weber and Osborn (1975) in phosphate continuous buffer system at $\mathrm{pH}$ 7.2. The molecular weight standards (with corresponding subunit molecular weights in parentheses) were bovine serum albumin $(67,000)$, pyruvate kinase $(57,000)$, ovalbumin $(45,000)$, chymotrypsinogen A $(25,000)$ and trypsin $(23,000)$.

Molecular weight determination The molecular weight of the native enzyme was determined by gel filtration in a $1.5 \times 96 \mathrm{~cm}$ Sephacryl S-200 column, using buffer A that contained $25 \mu \mathrm{M}$ NADP. The void volume of the column was determined with Blue Dextran. The standard proteins used in calibrating the column were ovalbumin $(45,000)$, bovine serum albumin $(67,000)$, hexokinase $(100,000)$, bovine gamma globulin $(150,000)$ and pyruvate kinase $(230,000)$. The ratio of elution volume of G6PD to the void volume was compared with corresponding ratios obtained for the standard proteins in order to determine the molecular weight of G6PD by linear regression. Protein standards were assayed by measuring the absorbance at $280 \mathrm{~mm}$. The elution of G6PD from the Sephacryl S200 column was monitored by assaying the enzyme fractions.

Assaying proteins and enzyme activity Protein concentrations were determined using the method of Lowry et al. (1957), using bovine serum albumin as standard. G6PD was assayed, using Cecil CE 595 double beam digital spectrophotometer, by measuring the absorbance of NADPH at $340 \mathrm{~mm}$. All assays were conducted in duplicate at $25^{\circ} \mathrm{C}$ according to the method of Lohr and Walker (1974), in a total reaction volume of $3 \mathrm{ml}$ and were initiated by the addition of enzyme to the reaction mixture. The enzyme, before it was assayed, was exhaustively dialysed against the assay buffer in order to remove any bound NADP. In a typical assay, the reaction mixture contained $50 \mathrm{mM}$ triethanolamine buffer $\mathrm{pH} 7.5,0.083$ $\mathrm{mM}$ NADP and $0.833 \mathrm{mM}$ glucose 6-phosphate (G6P). All solutions of G6P and NADP were appropriately buffered for all kinetic assays that were carried out.

Measurement of steady-state kinetic parameters The purified enzyme was dialysed extensively against $50 \mathrm{mM}$ triethanolamine buffer $\mathrm{pH}$ 7.5. First, steady-state kinetic studies were carried out by measuring reaction rates at varying concentrations of G6P for a series of constant concentrations of NADP. The concentration of G6P was varied between $0.05 \mathrm{mM}$ and $0.833 \mathrm{mM}$ while constant concentration of NADP was between $0.02 \mathrm{mM}$ and $0.5 \mathrm{mM}$. The experiment was repeated by varying the concentration of NADP between $0.02 \mathrm{mM}$ and $0.05 \mathrm{mM}$ at constant concentration of G6P which was between $0.05 \mathrm{mM}$ and $0.833 \mathrm{mM}$. The initial rate equation for the two-substrate reaction catalysed by G6PD, using the nomenclature of Cleland (1970) is

$$
\mathrm{v}=\frac{\mathrm{V}_{\max } \mathrm{AB}}{\mathrm{K}_{\mathrm{ia}} \mathrm{K}_{\mathrm{b}}+\mathrm{K}_{\mathrm{a}} \mathrm{B}+\mathrm{K}_{\mathrm{b}} \mathrm{A}+\mathrm{AB}}
$$


where A and B are NADP and G6P respectively.

The data that were obtained were analysed in accordance with data analysis devised by Cleland (1970)

Effect of temperature The effect of temperature on the reaction rate was studied between 25 and $55^{\circ} \mathrm{C}$. The energy of activation $\left(\mathrm{E}_{\mathrm{a}}\right)$ was calculated from the slopes of Arrhenius plot, which equals - $\mathrm{E}_{\mathrm{a}} /$ 2.303R (Lehrer and Barker, 1970; Low et al., 1973). The heat stability of the enzyme was determined by incubating it at $55^{\circ} \mathrm{C}$ at a protein concentration of $60 \mu \mathrm{g} / \mathrm{ml}$ in the assay buffer. Aliquots were removed at time intervals and inserted immediately in ice before each residual activity was determined at $25^{\circ} \mathrm{C}$.

Effect of divalent cations We investigated the effect of transition metal ions such as $\mathrm{Co}^{2+}, \mathrm{Ni}^{2+}, \mathrm{Zn}^{2+}, \mathrm{Cd}^{2+}$, and $\mathrm{Mn}^{2+}$ on A.aculeatus G6PD catalysed reaction in order to find out if the phenomenon of divalent transition metal ion-induced inactivation is a common one. Assays were carried out under standard conditions with varying concentration of each metal. The inhibition of the enzyme by $\mathrm{Zn}^{2+}$ and $\mathrm{Co}^{2+}$ was further examined by varying G6P concentration (50$500 \mu \mathrm{M})$ at a fixed NADP concentration $(83 \mu \mathrm{M})$ and at five different constant concentrations of each metal ion.

Regulatory ligands Several ligands, which are neither substrates nor products of G6PD catalysed reaction, have been found to affect the enzyme in-vitro. Many useful conclusions have been drawn from the results of such studies in the past. We tested the effects of many nucleotides, phosphoenolpyruvate (PEP), hexose phosphates and glycerol phosphate at a fixed concentration of each compound on the enzyme.

Product inhibition studies The inhibition of A.aculeatus glucose6-phosphate dehydrogenase by NAPDH was determined by measuring initial rates for a series of NADPH concentrations (0-33 $\mu \mathrm{M})$ with $0.417 \mathrm{mM}$ G6P and NADP concentrations varied from $20 \mu \mathrm{M}$ to $500 \mu \mathrm{M}$. A similar experiment was carried out at varying concentrations of G6P $(50-500 \mu \mathrm{M})$ at a fixed concentration of NADP $(83 \mu \mathrm{M})$ and NADPH concentrations, again, being varied from $0-33 \mu \mathrm{M}$. Inhibition constants were calculated using the equations for product inhibition in a bireactant enzyme system (Fromm 1975; Kanji et al., 1976)

\section{Results and Discussion}

Enzyme purification A summary of the purification procedure adopted in this report is presented in Table 1. The enzyme was purified approximately 230 fold with a 9\% yield and a specific activity of 220 units/mg protein. The $15-65 \%$ ammonium sulphate fraction contained more than $80 \%$ the active enzyme in the crude extract. However a considerable amount of the enzyme was lost along with other proteins on the Reactive Blue-2 Agarose column.

Molecular weight The molecular weight of the native enzyme was estimated by gel filtration to be $105,000 \pm 5,000$. The SDS-polyacrylamide gel electrophoresis revealed the presence of only one protein band which had a size of 52,000 \pm 1000 daltons. The enzyme, apparently, thus appeared to be homogenous. From the foregoing, A aculeatus G6PD would seem to be a dimer made up of two structurally equivalent subunits. Available reports indicate that functional glucose-6phosphate dehydrogenase in fungi, like other organisms (Levy, 1979), occurs either as dimers in Penicillium duponti (Malcolm and Shepherd, 1972) or as tetramers in $A$. parasiticus (Niehaus and Dilts, 1984). However, an unusual functional trimeric G6PD has been reported for A. niger and A. nidulans (Wennekes et al., 1993). There has not been any report on free, functional, monomeric species of the enzyme. The exact explanation for these discrepancies in the value of molecular weight of fungal G6PD is not available at the moment. In our investigation, $\varepsilon$-amino-n-caproic acid was added to the extraction buffer to prevent degradation by proteases, which have been reported to be present in fungus (Olutiola and Nwaogwugwu, 1982). Besides, a limited interaction of G6PD with gel filtration matrix during gel permeation chromatography, which would lead to retardation, thus yielding a falsely low value of molecular weight, could not be ruled out (Jagannathan et al., 1956).

Substrate and coenzyme specificity The specificity of $A$. aculeatus G6PD with respect to the pyridine nucleotides and sugar phosphate substrates was determined. In so doing, the nucleotides and substrate analogues were tested at concentrations that were ten times the $K_{m}$ values for NADP and G6P respectively. No detectable activity could be measured with $0.833 \mathrm{mM}$ glucose, $0.833 \mathrm{M}$ glucosamine 6-phosphate and $0.5 \mathrm{mM}$ NAD respectively.

Steady state kinetics The results of the initial velocity

Table 1. Purification of A. aculeatus glucose-6-phosphate dehydrogenase

\begin{tabular}{|c|c|c|c|c|}
\hline Procedure & $\begin{array}{l}\text { Total enzyme unit } \\
(\mu \mathrm{mol} / \mathrm{min})\end{array}$ & $\begin{array}{l}\text { Total protein } \\
(\mathrm{mg})\end{array}$ & $\begin{array}{c}\text { Specific activity } \\
(\mu \mathrm{mol} / \mathrm{min} / \mathrm{mg} \text { protein })\end{array}$ & Yield (\%) \\
\hline Crude extract & 2820 & 2930 & 0.96 & 100 \\
\hline $\begin{array}{c}15-65 \% \\
\left(\mathrm{NH}_{4}\right)_{2} \mathrm{SO}_{4} \text { Fraction }\end{array}$ & 2410 & 710 & 3.4 & 85 \\
\hline $\begin{array}{l}\text { Reactive Blue-2 } \\
\text { Agarose Affinity }\end{array}$ & 860 & 11 & 78 & 30 \\
\hline $\begin{array}{l}\text { Sephacryl S-200 } \\
\text { Gel Filtration chromatography }\end{array}$ & 260 & 1.2 & 220 & 9 \\
\hline
\end{tabular}


Table 2. Kinetic parameters of A. aculeatus glucose-6-phosphate dehydrogenase

\begin{tabular}{cc}
\hline Kinetic parameters & Values obtained \\
\hline$K_{m}{ }^{\text {NADP+ }}$ & $6 \pm 1 \mu \mathrm{M}$ \\
$K_{m}{ }^{\text {G6P }}$ & $75 \pm 6 \mu \mathrm{M}$ \\
$\mathrm{K}_{\mathrm{i}}{ }^{\text {NADP+ }}$ & $23 \pm 3 \mu \mathrm{M}$ \\
$\mathrm{K}_{\mathrm{is}}{ }^{\mathrm{NADPH}}$ (NADP varied) & $20 \pm 1 \mu \mathrm{M}$ \\
$\mathrm{K}_{\mathrm{is}}{ }^{\mathrm{NADPH}}$ (G6P varied) & $41 \pm 1 \mu \mathrm{M}$ \\
$\mathrm{K}_{\mathrm{ii}}{ }^{\mathrm{NADPH}}$ (G6P varied) & $43 \pm 1 \mu \mathrm{M}$ \\
\hline
\end{tabular}

studies for each of the two substrates indicated that the enzyme displayed a hyperbolic saturation curve. The same results gave linear double -reciprocal plots which converge at a point above the abscissa, an indication that $\mathrm{K}_{\mathrm{ia}}{ }^{\mathrm{NADP}}$ should be larger than $K_{m}^{\mathrm{NADP}}$ (Cleland 1970); and a situation which suggests that the binding of the fixed substrate lowers the apparent $K_{m}$ for the varied substrate. Indeed, the fact that $K_{m}{ }^{\mathrm{NADP}}$ is smaller than $\mathrm{K}_{\mathrm{ia}}{ }^{\mathrm{NADP}}$ (see Table 2) is an indication that G6P enhances the affinity of the enzyme for the coenzyme. A representative double reciprocal plot is shown in Fig. 1. Secondary plots of these results (insets of Fig. 1) were linear and yielded the kinetic constants which are summarized in Table 2. The linear and intersecting patterns of the double reciprocal plots rule out a ping-pong kinetic mechanism. However, the plots are consistent with a sequential mechanism in which both substrates must bind to the enzyme simultaneously before product formation can occur (Fromm, 1975). The turnover number, $\mathrm{k}_{\text {cat }}$, was calculated to be $83 \mathrm{sec}^{-1}$ while the specificity constants $\mathrm{k}_{\text {cat }} / K_{m}{ }^{\mathrm{NADP}}$ and $\mathrm{k}_{\mathrm{cat}} / K_{m}^{\mathrm{G} 6 \mathrm{P}}$ for the two substrates were $1.4 \times 10^{7} \mathrm{M}^{-1} \mathrm{~s}^{-1}$ and $1.1 \times 10^{6} \mathrm{M}^{-1} \mathrm{~s}^{-1}$ respectively.

Product and dead-end inhibition studies A careful analysis of the patterns of product inhibition studies can indicate the order of addition of substrates in sequential mechanism (Cleland, 1970). In inhibition studies obtained at different fixed concentrations of NADPH, when the concentrations of NADP and G6P are varied respectively, the intersection of the double reciprocal plots on the vertical axis indicated competitive inhibition with respect to NADP and non-competitive inhibition with respect to G6P (data not shown). However, the inhibition constants obtained from the figures, using the equations for bireactant enzymic systems (Fromm 1975; Kanji et al., 1976), are shown in Table 2. The patterns of inhibition studies are consistent with sequential mechanism that can be either compulsory-order mechanism in which NADP is bound first or a rapid-equilibrium random mechanism with a dead-end enzyme-G6P-NADPH complex. Different kinetic mechanisms have been reported for G6PD from various sources. While Soldin and Balinsky (1968), Olive et al. (1971) and Afolayan (1972) have described the mechanism of the enzyme as a sequential ordered one, Malcolm and Shepherd (1972), Levy and Cook (1991), Ragunathan and Levy (1994) and Wang et al. (2002) have proposed a random mechanism.
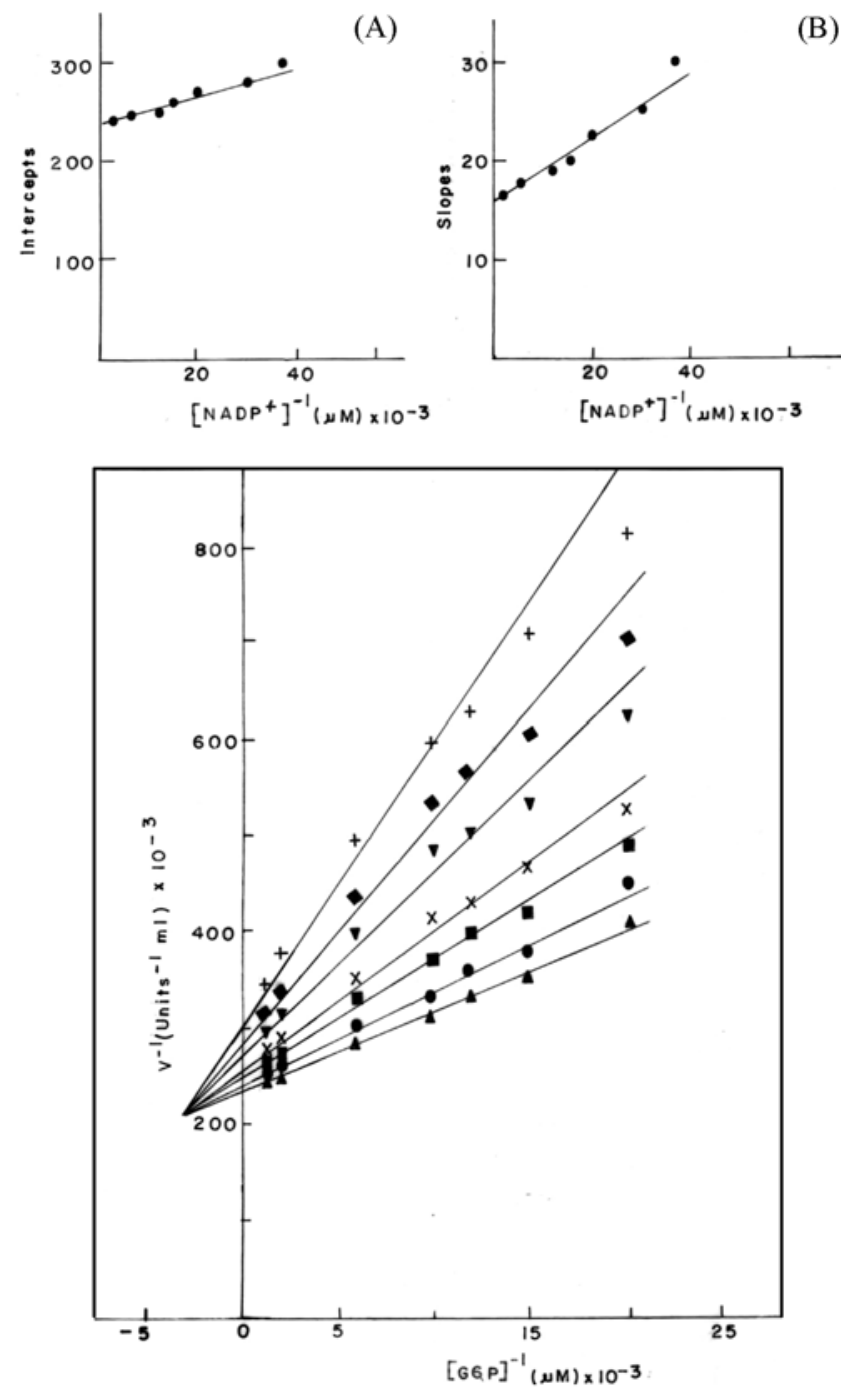

Fig. 1. Double-reciprocal plot for initial velocity versus glucose 6-phosphate concentration at $\mathrm{pH}$ 7.5. Concentrations of $\mathrm{NADP}^{+}$ were $27 \mu \mathrm{M}(+), 33 \mu \mathrm{M}(\diamond), 50 \mu \mathrm{M}(\boldsymbol{\nabla}), 67 \mu \mathrm{M}(\times), 83 \mu \mathrm{M}(\boldsymbol{\square})$, $167 \mu \mathrm{M}(\mathbf{O})$ and $500 \mu \mathrm{M}(\boldsymbol{\Delta})$. The inserts show (A) intercepts replot and (B) slopes replot, versus $\mathrm{NADP}^{+}$concentration respectively.

Glucosamine-6-phosphate reacts differently with different G6PDs. For some, it can serve as a weak substrate (Levy, 1979) while for some it is an inhibitor (Levy, 1979; Levy and Cook, 1991; Wang et al., 2002).On the other hand, and interestingly enough, Gn6P has been found to be an activator of G6PD from Azotobacter vinelandii (Anderson et al., 1997). In preliminary assay, we found that Gn6P could not be oxidized by $A$. aculeatus G6PD. As an analogue of G6P, Gn6P was therefore chosen as a dead-end inhibitor. The use of dead-end inhibitor can assist in the differentiation of sequential order from random order (Fromm, 1975; Levy and Cook, 1991; Wang et al., 2002). Glucosamine-6-phosphate was found to be a competitive inhibitor to G6P (Fig. 2) $\left(\mathrm{K}_{\text {is }}\right.$ $=21 \pm 1 \mathrm{mM}$ ) and a non-competitive with respect to NADP $\left(\mathrm{K}_{\mathrm{is}}=4.2 \pm 0.1 \mathrm{mM} ; \mathrm{K}_{\mathrm{ii}}=21 \pm 1 \mathrm{mM}\right)$. The inference from 


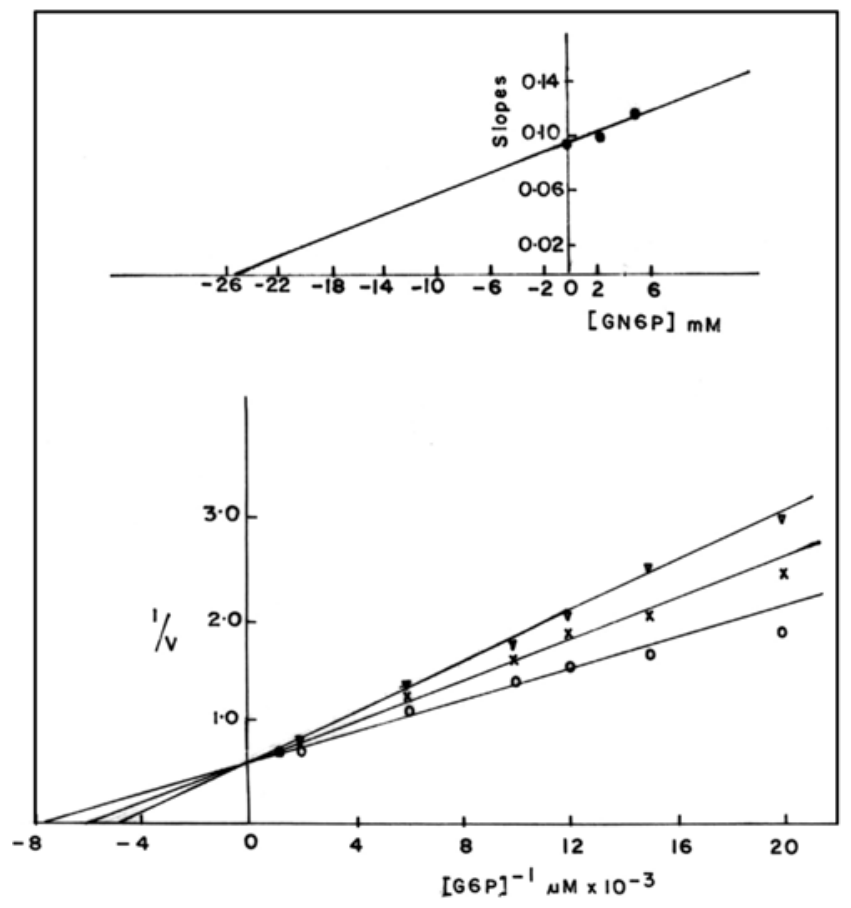

Fig. 2. Double reciprocal plots for inhibition by glucosamine 6phosphate. (A) NADP concentration was fixed at $83 \mu \mathrm{M}$. G6P concentration was varied from $50-833 \mu \mathrm{M}$ at glucosamine 6phosphate $0(\bigcirc), 2.5(\times)$ and $5(\nabla) \mathrm{mM}$.

Table 3. Effect of Various Ligands on A.aculeatus G6PD

\begin{tabular}{cc}
\hline Ligand (mM) & Percentage Activity \\
\hline None & 100 \\
ATP (2.0) & 78 \\
ADP (2.0) & 91 \\
AMP (2.0) & 103 \\
Phosphoenolpyruvate (2.0) & 69 \\
Fructose 6-phosphate (2.0) & 88 \\
\hline
\end{tabular}

All assays were carried out using concentrations of glucose-6phosphate and NADP that were five times their $K_{m}$ values (see Table 2)

these inhibition studies is that the dead-end inhibitor is capable of binding to both the free enzyme and G6PD-NADP complex. Since glucosamine 6-phosphate is an analogue of G6P, it is probable that the substrate (G6P) too can bind to both the free enzyme and enzyme -NADP complex. Thus, the inhibition studies seem to indicate that G6P and NADP can bind to the free enzyme. The recent information about the direct formation of crystal G6PD-G6P complex with human red cell G6PD (Wang et al., 2002) is also consistent with this suggestion. It therefore seems that, on the basis of limited inhibition studies, the kinetic mechanism of Aspergillus aculateus G6PD may be random. Perhaps it should be emphasized that the dividing line between compulsory - order and random mechanisms, through kinetic experiments, could be fuzzy. In a random order, an enzyme may bind either
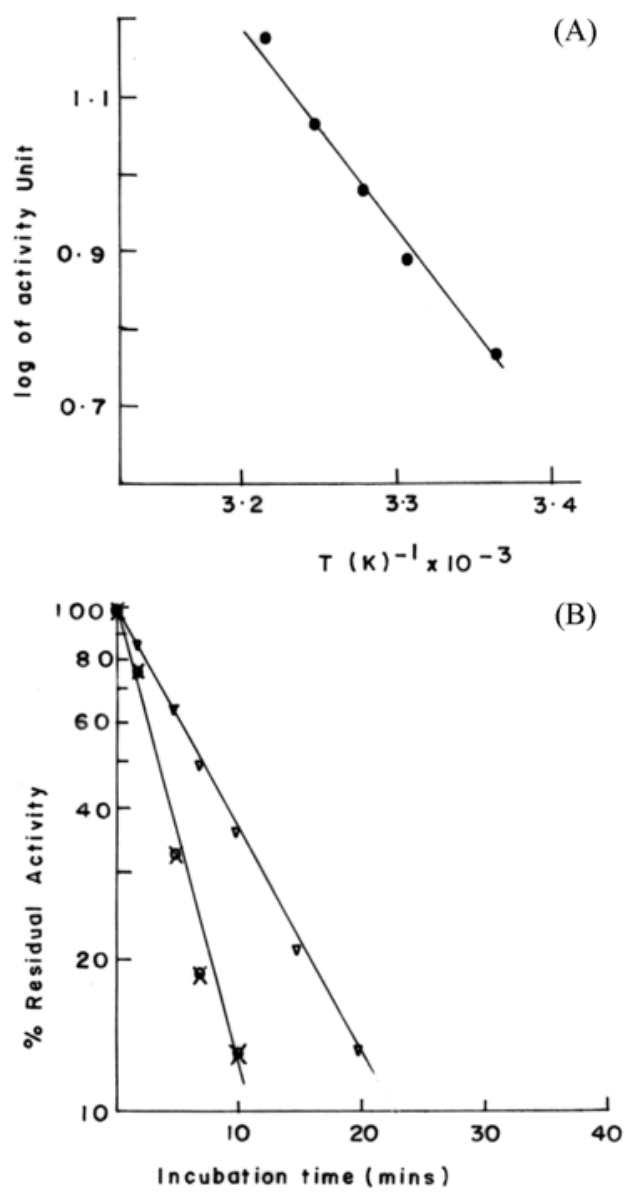

Fig. 3. (A) Effect of temperature on A.aculeatus G6PD. Arrhenius plot of temperature effect on the rate of G6PD catalyzed reaction (see experimental procedure). (B) Time-course of heat inactivation at $55^{\circ} \mathrm{C}$. The concentration of the enzyme in the incubation mixture was $60 \mu \mathrm{g} / \mathrm{ml}$ and in the presence of nothing $(\bigcirc), 100 \mu \mathrm{M}$ NADP $(\times)$ and $77 \mu \mathrm{M}$ G6P $(\nabla)$.

substrate first, but it is not likely that both routes will be equally probable.

Effect of possible regulatory ligands Several compounds were tested as possible regulatory effectors of the enzyme. The data presented in Table 3 are the results of such experiments. Phosphoenolpyruvate has been reported to be a potent inhibitor of G6PDs from several sources (Levy, 1979; Levy and Cook, 1991) However, the Aspergillus aculeatus G6PD, which is NADP specific, was not significantly inhibited under the conditions of our experiments. The enzyme, in this respect, is similar to the NADP-specific G6PD from Acetobacter hansenii which, also, was not inhibited by ADP and AMP (Levy and Cook, 1991).

Activation energy and thermostability studies The effect of temperature on the reaction rate of A. aculeatus G6PD was analysed using Arrhenius equation. A linear curve was obtained (Fig. 3), and from its slope, activation energy of 13 


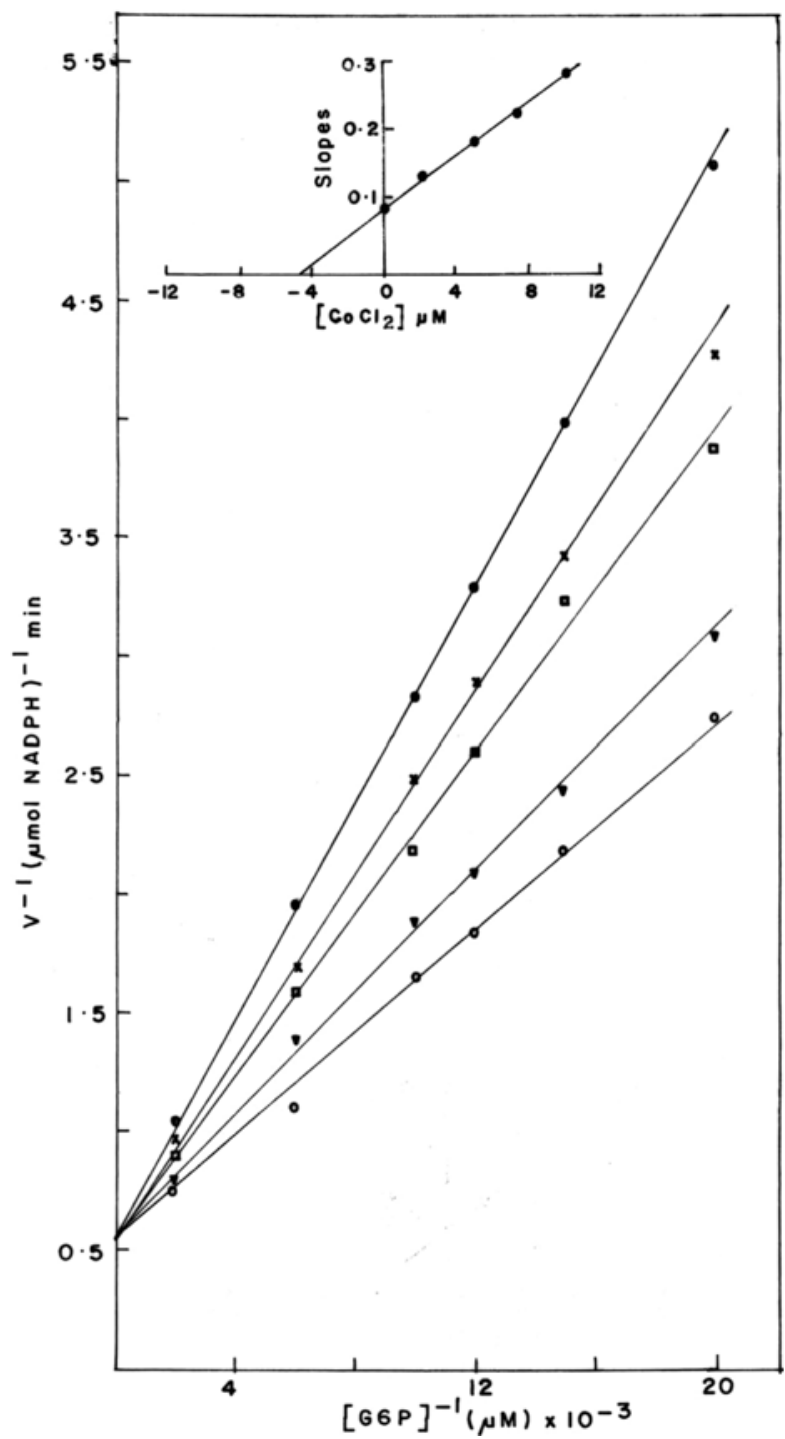

Fig. 4. Inhibition by divalent metal ion. NADP concentration was constant at $833 \mu \mathrm{M}$. Concentration of G6P was varied from 50$500 \mu \mathrm{M}$ at $\mathrm{Co}^{++}$concentrations of $0(\bigcirc), 2(\nabla), 5(\square), 7.3(\times)$ and $10(\mathbf{O}) \mu \mathrm{M}$.

$\mathrm{kcal} \mathrm{mol}^{-1}$ was obtained. The thermo -stability study of the enzyme at $55^{\circ} \mathrm{C}$ revealed that it was rapidly inactivated (Fig. $3)$. The inactivation was an irreversible linear process with a rate constant of $0.22 \mathrm{~min}^{-1}$ and a half life of $3.1 \mathrm{~min}$. While $100 \mu \mathrm{M}$ NADP did not offer any protection against heatinactivation (half life $=3.2 \mathrm{~min}$ ), $77 \mu \mathrm{M}$ G6P offered a slight degree of protection with a half life of $7.5 \mathrm{~min}$. The protection against heat-inactivation offered by G6P, seems to be a phenomenon unique to fungal G6PDs in view of the report of Malcolm and Shepherd (1972) on penicillium G6PD that displayed a similar irreversible linear inactivation profile but was protected by glucose 6-phosphate.

Effect of divalent metal ions We found that $A$. aculeatus G6DP was inhibited by $\mathrm{Zn}^{2+}$ and other transition metal ions
Table 4. Inhibition of $A$. aculeatus glucose-6-phosphate dehydrogenase activity by divalent cations.

\begin{tabular}{cc}
\hline Ion* & Activity remaining $(\%)$ \\
\hline None (control) & 100 \\
$\mathrm{Co}^{2+}$ & 40 \\
$\mathrm{Zn}^{2+}$ & 60 \\
$\mathrm{Cd}^{2+}$ & 83 \\
$\mathrm{Ni}^{2+}$ & 79 \\
$\mathrm{Mn}^{2+}$ & 72 \\
\hline
\end{tabular}

Enzyme assays were carried out under standard assay condition (section on experimental procedures). The final concentration of each cation in the assay mixture was $10 \mu \mathrm{M}$.

such as $\mathrm{Ni}^{2+}, \mathrm{Co}^{2+}$ and $\mathrm{Cd}^{2+}$. The inhibitions by $\mathrm{Zn}^{2+}$ and $\mathrm{Co}^{2+}$ ions were competitive with respect to G6P (Fig. 4) with a $\mathrm{K}_{\mathrm{i}}$ values of $6.6 \pm 0.1 \mu \mathrm{M}$ and $4.7 \pm 0.1 \mu \mathrm{M}$ respectively. Of all the divalent metals tested, $\mathrm{Co}^{2+}$ was the most potent inhibitor (Table 4). At $10 \mu \mathrm{M}, \mathrm{Co}^{2+}$ inhibited the enzyme by $60 \%$ compared with $\mathrm{Zn}^{2+}$ which caused $40 \%$ inhibition .Transition metal ions such as $\mathrm{Zn}^{2+}$ and $\mathrm{Co}^{2+}$ have been shown to be inhibitors of glucose- 6 phosphate dehydrogenase from a number of sources and, in each case, the inhibition by zinc ion was also linear competitive with respect to glucose-6phosphate (Niehaus and Dilts, 1984)

The probable significance of inhibition of $A$. aculeatus G6PD by zinc can be assessed from the fact that, in imperfect fungi, zinc ion has been shown to stimulate the production of polyketides and also to cause the inhibition of mannitol dehydrogenase (Hult and Gatenbeck, 1978; Niehaus and Dilts, 1982). Generally, polyketide formation is favoured by limiting the production of NADPH that is generated by the catalytic activities of fungal dehydrogenases such as G6PD (Niehaus and Dilts, 1984), 6-phosphogluconic dehydrogenase (Niehaus et al., 1996) and mannitol dehydrogenase (Hult and Gatenbeck, 1978; Niehaus and Dilts, 1982). In other words a low NADPH/NADP ratio is favoured by zinc ion. The relationship between the NADPH/NADP ratio and the regulation of G6PD activity has long been recognized (Afolayan, 1972; Eggleston and Krebs, 1974). The inhibition of Aspergillus aculeatus G6PD by the transition metal ions is perhaps another means of controlling the pentosephosphate pathway at low NADPH/NADP ratio that is known to favour the operation of the mannitol cycle in many imperfect filamentous fungi, including Aspergillus species. For, the operation of mannitol cycle, in the presence of zinc ion, leads to a stimulated synthesis of mycotoxin versicolorin A which is a precursor of polyketide aflatoxin (Niehaus and Dilts, 1982). But not all Aspergillus species produce polyketides (Foreman and Niehaus, 1985). The full significance of the inhibition of $A$. aculeatus glucose-6-phosphate dehydrogenase activity by zinc and other transition metal ions may be strengthened by the outcome of future investigation in to the synthesis, or otherwise, of polyketide mycotoxins in this infectious filamentous fungus. 
Acknowledgments This research was supported partly by research grant Nos 1425EJ, 1425FV and 1425RE from the University Research Committee of the Senate of Obafemi Awolowo University, Ile-Ife.

\section{References}

Afolayan, A. (1972) Regulation and kinetics of glucose-6phosphate dehydrogenase from Candida utilis. Biochemistry 11, 4172-4178.

Anderson, B. M., Wise, D. J. and Anderson, C. D. (1997) Azotobacter vinelandii glucose 6-phosphate dehydrogenase properties of NAD- and NADP-linked reactions. Biochim. Biophys. Acta. 1340, 268-276.

Cleland, W. W. (1970) Steady state kinetics; in The Enzymes, Paul D. Boyer, (ed.) pp. 1-61, Academic Press, New York, USA.

Cruickshank, R., Duguid, J. P., Marmion, B. P. and Swain, R. H. (1975) Cultivation of bacteria, fungi and protozoa: culture media; in Medical Microbiology, Cruickshank, R., Duguid, J. P., Marmion, B. P. and Swainm R. H. (eds.), pp. 99-150, Churchill Livingstone, London, UK.

Dijkema, C., PelsRijcken, R., Kester, H. C. and Visser, J. (1986) ${ }^{13} \mathrm{C}$-NMR studies on the influence of $\mathrm{pH}$ and nitrogen source on the polyol pool formulation in Aspergillus nidulans. FEMS. Microbiol. Lett. 33, 125-131.

Dijkema, C., Kester, H. C. and Visser, J. (1985) ${ }^{13}$ C-NMR studies on carbon metabolism in the hyphal fungus Aspergillus nidulans. Proc. Natl. Acad. Sci. USA 82, 14-18.

Eggleston, L. V. and Krebs, H. D. (1974) Regulation of the pentose phosphate cycle. Biochem. J. 138, 425-435.

Foreman, J. E. and Niehaus, W. G. (1985) $\mathrm{Zn}^{2+}$-induced cooperativity of mannitol1-phosphate dehydrogenase from Aspergillus parasiticus. J. Biol. Chem. 260, 10019-10022.

Fromm, H. J. (1975) Initial rate enzyme kinetics; in Initial Rate Enzyme Kinetics, Fromm, H. J. (ed.), pp. 41-120, SpringerVerlag, New York, USA.

Hult, K. A. and Gatenbeck, S. (1978) Production of NADPH in the mannitol cycle and its relation to polyketide formation in Alternaria alternata. Eur J. Biochem. 88, 607-612.

Jagannathan, V., Rengachari, P. N. and Damodaran, M. (1956) Carbohydrate metabolism in citric acid fermentation. 5. Purification and properties of Zwischenferment from A. niger. Biochem. J. 64, 477-481.

Kanji, M. I., Toews M. R. and Carper W. R. (1976) A kinetic study of glucose 6-phosphate dehydrogenase. J. Biol. Chem. 251, 2258-2262.

Lehrer, G. M. and Barker, R. (1970) Conformational changes in rabbit muscle aldolase. Kinetic studies. Biochemistry 9, 15331540.

Levy, H. R. (1979) Glucose 6-phosphate dehydrogenases. $A d v$. Enzymol. Relat. Areas Mol. Biol. 48, 97-192.

Levy, H. R. and Cook, C. (1991) Purification and properties of NADP-linked glucose 6-phosphate dehydrogenase from Acetobacter hansenii (Acetobacter Xylinum). Arch. Biochem. Biophys. 291, 161-167.
Lohr, G. W. and Waller, H. D. (1963) Glucose-6-phosphate dehydrogenase; in Methods in Enzymatic Analysis, Bergmeyer, H. U. (ed.), pp. 744-751, Verlag Chemie, Weinheim, Germany.

Low, P. S., Bada, J. L. and Somero, G. N. (1973) Temperature adaptation of enzymes: roles of the free energy, the enthalpy, and the entropy of activation. Proc. Natl. Acad. Sci. USA 70, 430-432.

Lowry, D. H., Rosebrough, N. J., Farr, A. L. and Randall, R. J. (1957) Protein measurement with folin phenol reagent. J. Biol. Chem. 193, 265-275.

Malcom, A. A. and Shepherd, M. G. (1972) Purification and properties of penicillum glucose-6-phosphate dehydrogenase. Biochem. J. 128, 817-831.

McCullough, W., Payton, M. A. and Robert C. F. (1977) Carbon metabolism in Aspergillus nidulans; in Genetics and Physiology of Aspergillus, Smith J. E. and Pateman J. A. (eds.) pp. 97-129, Academic Press, New York, USA.

Niehaus, W. G. and Dilts, R. P. (1982) Purification and characterization of mannitol dehydrogenase from Aspergillus parasiticus. J. Bacteriol. 151, 243-250.

Niehaus, W. G. and Dilts, R. P. (1984) Purification of glucose-6phosphate dehydrogenase from Aspergillus parasiticus. Arch. Biochem. Biophys. 228, 113-119.

Niehaus, W. G., Richardson, S. B. and Wolz, R. L. (1996) Slowbinding inhibition of 6-phosphogluconate dehydrogenase by zinc ion. Arch. Biochem. Biophys. 333, 333-337.

Olive, C., Geroch, M. E. and Levy H. R. (1971) Glucose 6phosphate dehydrogenase from Leuconostoc mesenteroides. Kinetic studies. J. Biol. Chem. 246, 2047-2057.

Olutiola, P. O. and Nwaogwugwu, R. I. (1982) Growth, sporulation and production of maltase and proteolytic enzymes in Aspergillus aculeatus. Trans. Brit. Mycol. Soc. 78, 105-113.

Ragunathan, S. and Levy H. R. (1994) Purification and characterization of the NAD-preferring glucose 6-phosphate dehydrogenase from Acetobacter hanseni (Acetobacter xylinum). Arch. Biochem. Biophys. 310, 360-366.

Soldin, S. J. and Balinsky, D. (1968) The kinetic properties of human erythrocyte glucose 6-phosphate dehydrogenase. Biochemistry 7, 1077-1082.

Wang, X. T., Au, S. W., Lam, V. M. and Engel P. C. (2002) Recombinant human glucose-6-phosphate dehydrogenase. Eur. J. Biochem. 269, 3417-3424.

Weber, K. and Osborn, M. (1975) Proteins and sodium dodecyl sulphate. Molecular weight determination on polyacrylamide gels and related procedures; in The Proteins, Neurath, H. and Hill, R. L. (eds.), pp. 179-223. Academic Press, New York, USA.

Wennekes, L. M., Goosen, T., van den Brock, P. J. and van den Brock H. W. (1993) Purification and characterization of glucose-6- phosphate dehydrogenase from Aspergillus niger and Aspergillus nidulans. J. Gen. Microbiol. 139, 2793-2800.

Williams, B., Popoola, B. and Ogundana, S. K. (1984) A possible new human pathogenic Aspergillus. Isolation and general mycological properties of the fungus. Afr. J. Med. Sci. 13, 111115. 